\title{
Housing Market in Capital Cities - the Case of Poland and Portugal
}

Abstract: The real estate markets in capital cities are considerably different from the other regions of their respective countries. Due to the higher level of investment, business activity and income, increased tourism, and demand for real estate (and the subsequent higher prices), the markets in capital cities are usually more developed and more valuable; however, they describe the degree of development of the national real estate market to a certain extent. The aims of this paper are to conduct a comparative study of the housing prices in Warsaw and Lisbon (the capital cities of Poland and Portugal, respectively) using some macroeconomic variables and to measure the influence of factors including wages, supply of houses, and unemployment on the housing prices of the cities of Warsaw and Lisbon. We analyzed data from the period of 2009 through 2015. The following research methods were used in the research: a literature review, secondary data sources research, and statistical methods (the correlation, simple, and multiple regression techniques). We determined which factors affect the housing prices in the cities of Warsaw and Lisbon and to what extent this occurs.

Keywords: housing, housing market, price dynamics

* The President Stanisław Wojciechowski State University of Applied Sciences in Kalisz, Kalisz, Poland

** Polytechnic Institute of Bragança, Bragança, Portugal 


\section{Introduction}

The real estate market is of vital importance for an economy, being one of the most important markets in the developed economies on provisional rent and investment levels on the one hand and as a source of guarantee for bank loans on the other hand.

The real estate market is an interesting field of research, both at the macro and micro levels. On the macro level, real estate is closely related to the financial and business sector; therefore, the real estate market is an important part of any country's economic analysis. It is believed that the integration of real estate markets around the world is one of the key features of globalization. Also, it has been seen that the real estate markets are highly correlated during times of crisis.

The real estate market is a dynamic system that is subject to changes taking place in the environment; it is characterized by its surroundings and functional bonds. The financing subsystem includes the availability of mortgage loans for buyers (mortgages) or investment loans for developers, for example [1]. The political environment consists of various forms of local and governmental authority, political risk, constitutional principles, participation in international organizations, and political climate at the national level. The economy affects the real estate market through a resource allocation system, interest rates, inflation rate, exchange rates, the industrial and spatial structure of the country, the structure of economic activity, the organization and development of capital and money markets, market opening levels, and tax system (reliefs and other investment incentives). The social environment is determined by race, culture, social relationships, class structure, and behavior. The legal environment consists of legal regulations such as rights to real estate, rules of real estate turnover, spatial development, construction, inheritance, and taxation. The real estate market is influenced by the provisions of the constitution, interpretation of regulations, differences in the application of law on a regional basis, and impact of international law (e.g., European Union directives) on national and local regulations.

An important segment of the real estate market is the residential real estate market, which generates a large share of turnover. Real estate is important for any type of business. Land is one of the three basic factors of production. Those properties that are not directly used for production (such as residential properties) support production and give people a place where they can live.

\section{Location Theory}

Based it on the economic theory of land rent, the first spatial location theory was authored by J.H. von Thünen [2], who presented a rational model of the intensity of agricultural land use. Around the city, which is a market, there is an intensive culti- 
vation of vegetables, soft fruit, and milk production in the first concentric zone (i.e., perishable and fresh products). In subsequent zones, the intensity of agricultural land use decreases and further circles of forest management occur. As the distance from the city increases, we can notice: forests, extensive cultivation of cereals and potatoes, animal husbandry, and cereal crops for farmers' own needs.

Then, M. Weber presented the theory of the optimal location of an industrial enterprise, distinguishing three basic factors of its location: transport costs, labor costs, and agglomeration benefits. This theory explained the location of heavy industry based on the exploitation of mineral and energy resources as well as the development of industrial districts. The criterion of optimal location was to minimize transport costs in relation to the costs of production and consumption.

The theory of the location also includes Christaller's theory of central centers [3], which is based on the principle of centrality. It allows us to identify cities that play the roles of main centers (central markets) in relation to the surrounding spaces. The areas of impact of individual cities are hierarchically positioned, creating a hexagonal model (based on a regular hexagon system). Christaller has identified seven levels of hierarchical cities: capital, provincial, transregional, regional, district, commune, and trade fair cities.

Most theoretical models of housing location start from the monocentric model associated with Alonso [4] and Muth [5]. The basic model assumes that households work in a single location in the city but choose between living in the city center and out-of-town (access versus space). Since commuting to the city center involves both time and transport costs, the price of housing and land must fall when distance from the city center increases.

In economic geography [6-8], attention is paid to the non-economic factors of the location of economic activities undertaken by people who do not always act in accordance with rational and complete knowledge about their environment. Despite the popular opinion on independence from spatial location due to the progress in the field of information and communication, it has been shown that the location of financial services shows a strong concentration in metropolises. Metropolises usually are service centers. The largest towns bit by bit abandon purely productive profiles. For this reason, metropolises (especially state capitals) are different from other local markets. They are characterized by different terms of concluding transactions and a higher level of investment that cause a greater demand for real estate, resulting in a higher price level. The locality of real estate markets is a key issue when analyzing the market. Residential real estate is much more related to location than investment real estate, for example. When making an investment decision, investors often go beyond the local market [9]. The subject of local real estate markets was dealt with by Lund [10] and Ranci, Brandsen, and Sabatinelli [11]. The locality of the real estate market has also been confirmed by research carried out by Dziauddin, Ismail, and Othman [12] as well as Bełej and Kulesza [13], who demonstrate the diversification of the strength of the influence 
of significant factors on the levels of housing prices on the markets of individual cities. The factors affecting the housing market include the population, age structure of the population, family situation (number of households), employment, wage level, income stability, propensity to save, availability of loans, condition and structure of the housing stock in a given area, rents, vacancy rate, availability and prices of land for new investments, prices and availability of building materials, and others. The real estate market remains sensitive to social, demographic, political, and economic changes in a given area [14]. In the case of capital cities, the situation on the real estate market is first of all affected by macroeconomic factors such as CACs, state investment attractiveness, share of foreign investments in total investments, attractiveness of the labor market, etc.

In connection with the above, the situations in the housing markets of Warsaw and Lisbon was analyzed during the period of 2009-2015 in order to identify the similarities and differences between the residential property markets in the Polish and Portuguese capitals as well as the factors affecting the real estate markets in these cities.

\section{Analysis of Residential Real Estate Markets in Selected Countries}

\subsection{Housing Market in Poland}

The macroeconomic environment of the housing market reflects the economic situation of a country. Similar to other European Union countries, the economic situation in Poland is assessed by means of the so-called business climate test, whose results (business climate indices) allow us to determine the business climate cycle that reflects the state of the economy [15]. The globalization of economic processes as well as the growing role of the flow of capital, goods, and services within the international system make it impossible to separate the processes on the Polish housing market from international influence.

Like in many other countries, the housing market in Poland has gone through a period of rapid systemic changes connected with the global economic crisis. In Poland, the dynamic growth of market mechanisms focusing on satisfying the public housing started in 1989 along with the transformation of the political system, which proves the opinion that the housing market is a function of structural and political factors. Poland started the period of transformation with a relatively low level of housing in 1991; some 3.6 new housing units (houses or flats) were built per 1000 inhabitants. The main suppliers of flats were housing cooperatives that built more than 83,000 flats. Most of the flats in multi-family construction were built using large-panel technologies [16].

The high global competitiveness index of Poland $(G C I=4.5669)$ can contribute to the development of its housing market by evaluating the quality of the macroeco- 
nomic environment, condition of the public institutions, and technological level of a given country. The Index of Economic Freedom (IEF $=68.5)$ measures the level of the property rights protection and for Poland it is quite high. [17].

According to preliminary data, 162,727 dwellings were completed in 2016; i.e., $10.2 \%$ more than in 2015 , when the number of dwellings increased by $3.2 \%$. During the 12-month period of 2016, the number of dwellings for which building permits were granted or that were registered with a construction project amounted to 211,565; i.e., 12.0\% more than in 2015 (against an increase by 20.5\% the year before). The number of dwellings in which construction began also increased to 173,932; i.e., 3.3\% (against an increase by 13.7\% the year before) [18]. The pace of changes in the supply of apartments in Poland was the greatest between 2007 and 2009, when the number of new apartments offered, new constructions started, and building permits issued reached their peak and bottom values in 2007 and 2009, respectively.

One of the main causes of the changes in the housing market was the dramatic decrease in lending by the banking sector, resulting mainly from the turmoil in the global financial market and deterioration of the socio-economic and demographic situation of the country [19]. During the 12-month period of 2016, there were more dwellings completed than the year before. The number of dwellings for which permits were granted or that were registered with a construction project as well as the number of dwellings in which construction began also increased [18].

At the end of 2016, the primary market in Warsaw saw a transaction price at PLN 7686/m², while Krakow and Poznan saw prices of PLN 6469 and 6285/m², respectively. The secondary market observed the highest transaction price as of the end of 2016 in Warsaw (PLN 7231/m²), Krakow (PLN 5942/m²), and Wroclaw (PLN 5480/m²). House prices in Warsaw changed at a very minimal rate from 2012 to 2015. Although the economy of Poland recovered slowly, housing prices continued to fall. The price declined drastically from 2010 until the end of 2011 because of the economic downturn, oversupply of housing, and limited supply of credit [20]. The prices increased again during the period of 2012 through 2015.

\subsection{Housing Market in Portugal}

In terms of square meter prices, Portugal has some of the lowest prices in Europe for a city center property. Property cap rates and market values differ not only within the two largest main cities in Portugal (Lisbon and Porto) but also between them [21]. The recovery of the Portuguese economy depends on the success of fiscal consolidation, which means a change in government consumption and expenditure. Moreover, the downturn of the Portuguese housing stock is not a consequence of the typical cyclical downturn but is rather the result of a high level of debt that, added to the increased budget constraints of households and high employment rate, jeopardizes the recovery of the housing market [22].

Between 1985 and 1998, house prices rose by about one per cent a year in Portugal. Between 1999 and 2006, house prices registered zero-annual growth. The housing 
prices grew less than one percent per year on average until the beginning of the financial crisis in 2007. In Portugal, residential investment had been declining since the end of the 90s. Between 2007 and 2013, residential investment fell at an annual average rate of about $12 \%$.

In the Portuguese case, the unit price is obtained from bank appraisals through Statistics Portugal and the Bank of Portugal, which are collected through a monthly survey, gathering information on homes that are objects of bank financing. In the third quarter of 2016, the House Price Index (HPI) in Portugal increased by $7.6 \%$ when compared to the same period of 2015 (6.3\% in the previous quarter). This was the highest price increase ever observed and the third consecutive quarter in which the HPI recorded an annual rate of change above $6 \%$. In the third quarter of 2016, the house sales indicator totaled 31,535 transactions, 26,341 of which were purchases of existing dwellings, with this last figure representing a new maximum in the available series. During this period, the value of transacted dwellings exceeded 3.6 billion euros, which represents a $17.6 \%$ increase when compared with the same quarter of the previous year.

The construction industry in Portugal has been called the engine of the economy, and the housing market is a non-negligible portion of the construction industry. Construction can represent the main driver behind economic recovery, as the crisis in the economy is directly linked to the crisis in the construction industry.

The housing market in Lisbon had been in depression since 2010; however, it started to recover in 2013. Housing prices fell continuously from the end of 2010 until the third quarter 2013, with an accumulated drop of $14 \%$. Since then prices had been rising. After the recession, house prices had some recovery in 2009 and then started to fall again in the last quarter of 2010. But then again, at the end of 2013 and throughout 2014, there was a visible recovery in this sector, after three consecutive years of house price declines. If inflation was considered, price declines would be larger. This gives a more meaningful guide to how house prices have increased compared to typical prices in the economy.

\subsection{Comparison of Housing Market in Lisbon and Warsaw}

We compared the housing markets in both capital cities, summarizing the results in Table 1.

Table 1. Comparison of Warsaw and Lisbon housing markets

\begin{tabular}{||l|c|c|c|c|c|c|c||}
\hline \multicolumn{1}{|c|}{ City } & 2009 & 2010 & 2011 & 2012 & 2013 & 2014 & 2015 \\
\hline \hline Housing prices [EUR] \\
\hline Warsaw* & 1749 & 1973 & 1834 & 1627 & 1704 & 1755 & 1788 \\
\hline Lisbon & 1412 & 1425 & 1355 & 1232 & 1198 & 1205 & 1255 \\
\hline
\end{tabular}


Table 1. cont.

\begin{tabular}{|c|c|c|c|c|c|c|c|}
\hline \multicolumn{8}{|c|}{ Change in housing prices [\%] } \\
\hline Warsaw & 4 & -4 & -10 & 5 & 3 & 2 & 4 \\
\hline Lisbon & 1 & -5 & - & -3 & 1 & 4 & 1 \\
\hline \multicolumn{8}{|c|}{ Real GDP growth rate } \\
\hline Warsaw & 2.8 & 3.6 & 5.0 & 1.6 & 1.3 & 3.3 & 3.6 \\
\hline Lisbon & -3.0 & 1.9 & -1.8 & -4.0 & -1.1 & 0.9 & 1.5 \\
\hline \multicolumn{8}{|c|}{ Housing development intensity } \\
\hline Warsaw & \multicolumn{7}{|c|}{$\begin{array}{l}\text { Poland is listed in the countries with above average housing develop- } \\
\text { ment intensity }\end{array}$} \\
\hline Lisbon & \multicolumn{7}{|c|}{$\begin{array}{l}\text { The residential market in Portugal appear to be rather saturated as evi- } \\
\text { denced by the relatively low housing development intensity }\end{array}$} \\
\hline \multicolumn{8}{|c|}{ Affordability } \\
\hline Warsaw & \multicolumn{7}{|c|}{ Housing in Poland falls into a less affordable category } \\
\hline Lisbon & \multicolumn{7}{|c|}{ Relatively affordable housing can be found in Portugal } \\
\hline \multicolumn{8}{|c|}{ New dwelling price } \\
\hline Warsaw & \multicolumn{7}{|c|}{ Average size of new dwelling in Poland for EUR 200,000 is $181 \mathrm{~m}^{2 * *}$} \\
\hline Lisbon & \multicolumn{7}{|c|}{ Average size of new dwelling in Portugal for EUR 200,000 is $194 \mathrm{~m}^{2}$} \\
\hline
\end{tabular}

* The data collected for housing prices in Warsaw was in PLN; but, if we convert it to euros, it can be noted that the prices per square meter are higher in Warsaw than in Lisbon. $* *[23]$.

\section{Methods and Models}

A quantitative approach with secondary sources of data has been used in this study, and all of the data has been collected from different national databases and websites. The databases used to collect the data for Poland are Narodowy Bank Polski (National Bank of Poland, NBP) and the Polish Local Data Bank (BDL). Most of the data was collected on a yearly basis from 2009 to 2015. The house prices for Poland have been collected from NBP (Poland). The NBP database is created by the voluntary sharing of data by real estate agents and the developers of NBP, whereas the data about housing prices in Lisbon is based on bank appraisals (nominal prices). The other variables used in this study are inflation, annual wages, population, unemployed population, and number of dwellings in the respective cities.

The variables used in this study are mentioned in Table 2 along with a short description of each variable. All explanatory variables were presented as mean or relative values. 
Table 2. Description of data

\begin{tabular}{||l|l||}
\hline \multicolumn{1}{|c|}{ Variable } & \multicolumn{1}{c|}{ Description } \\
\hline \hline Inflation & General prices increase of goods and services \\
\hline Income & Average monthly net income and salaries of households \\
\hline Unemployment & Registered unemployed persons per population [\%] \\
\hline Number of houses & $\begin{array}{l}\text { Number of dwellings in residential and non-residential buil- } \\
\text { dings per population }\end{array}$ \\
\hline Average unit house price & Dependent variable \\
\hline
\end{tabular}

A strong correlation between the average unit house price and only three of the four dependent variables can be observed. For this reason, the outlying variable (which is the inflation rate) was not accepted as an explanatory variable in the model.

Regression models for two countries were built, and the results for Poland are shown in Table 3. In case of three independent variables, the model explain quite well (coefficient of determination $R^{2} 69 \%$ ) the changes in housing prices. Next, we have examined the adjusted $R^{2}$, which considers missing data, deleting, adding data, and adding or removing independent factors. The adjusted $R^{2}$ is only $38 \%$. When the first multiple regression was conducted with the three independent variables, the slopes of the regression did not depict their expected signs. For example, note that income had a negative slope when it in fact should have had a positive one; that is, when the income increases, house prices should also increase. The same applies to the no. of houses, which is positively related to the dependent variable but should have been negative. The reason for the incorrect slopes could be explained by the high multicollinearity of the test. The results show the Significance $F$ value and the $p$-values are larger than a significance level of 0.05 , which means that the model is not reliable.

More regressions were conducted with different combinations of the chosen variables, and none of the models were reliable; this means that the chosen independent variables are not significant enough to determine the housing prices in Warsaw.

Table 3. Regression statistics, dependent variable - house price

\begin{tabular}{||l|c||}
\hline \multicolumn{1}{|c|}{$\begin{array}{c}\text { Regression } \\
\text { statistics }\end{array}$} & Three variables \\
\hline \hline Multiple $R$ & 0.831 \\
\hline$R^{2}$ & 0.690 \\
\hline Adjusted $R^{2}$ & 0.380 \\
\hline Standard error & 3.568 \\
\hline Observations & 7 \\
\hline
\end{tabular}


Table 3. cont.

\begin{tabular}{||l|c|c|c|c|c|c||}
\hline \multicolumn{1}{|c|}{ Anova } & $d f$ & $S S$ & \multicolumn{2}{c|}{$M S$} & $F$ & Significance $F$ \\
\hline Regression & 3 & 85.031 & 28.344 & 2.226 & 0.264 \\
\hline Residual & 3 & 38.197 & \multicolumn{2}{c|}{12.732} & - & - \\
\hline Total & 6 & 123.229 & \multicolumn{2}{|c|}{-} & - & - \\
\hline Characteristics & $\begin{array}{c}\text { Coeffi- } \\
\text { cients }\end{array}$ & $\begin{array}{c}\text { Standard } \\
\text { error }\end{array}$ & $t$ stat. & $p$-value & $\begin{array}{c}\text { Lower } \\
95 \%\end{array}$ & $\begin{array}{c}\text { Upper } \\
95 \%\end{array}$ \\
\hline Intercept & -8.117 & 93.062 & -0.087 & 0.936 & -304.290 & 288.047 \\
\hline Net income & -0.667 & 0.501 & -1.333 & 0.275 & -2.261 & 0.926 \\
\hline No. of houses & 1.921 & 1.375 & 1.397 & 0.257 & -2.455 & 6.298 \\
\hline Unemployment & -0.176 & 0.079 & -2.239 & 0.111 & -0.427 & 0.074 \\
\hline \hline
\end{tabular}

The results for Portugal are shown in Table 4. Coefficient of determination $R^{2}$ in the case of three independent variables explains $95 \%$ of the variation in the housing prices. Next, we have examined the $R^{2}$ with adjusted $R^{2}$, which considers missing data, deleting, adding data, and adding or removing independent factors. The adjusted $R^{2}$ is $90 \%$; this shows that $5 \%$ of the data is lost with the use of these factors. The slopes of all of the variables in this regression had the correct signs. The results show the significance $F$ value is smaller than a significance level of 0.05 , which means that the model is fit. However, the $p$-values of the variables are not reliable, which can be due to the multicollinearity between the independent variables. It is common that, when conducting a multiple regression analysis, some of the independent variables are correlated with each other.

Table 4. Regression statistics, dependent variable - house price

\begin{tabular}{|c|c|c|c|c|c|c|}
\hline $\begin{array}{l}\text { Regression } \\
\text { statistics }\end{array}$ & \multicolumn{6}{|c|}{ Three variables } \\
\hline Multiple $R$ & \multicolumn{6}{|c|}{0.975} \\
\hline$R^{2}$ & \multicolumn{6}{|c|}{0.950} \\
\hline Adjusted $R^{2}$ & \multicolumn{6}{|c|}{0.901} \\
\hline Standard error & \multicolumn{6}{|c|}{2.183} \\
\hline Observations & \multicolumn{6}{|c|}{7} \\
\hline Anova & $d f$ & SS & \multicolumn{2}{|c|}{$M S$} & $F$ & Significance $F$ \\
\hline Regression & 3 & 273.246 & \multicolumn{2}{|c|}{91.082} & 19.104 & 0.019 \\
\hline Residual & 3 & 14.303 & \multicolumn{2}{|c|}{4.768} & - & - \\
\hline Total & 6 & 287.549 & \multicolumn{2}{|c|}{-} & - & - \\
\hline Characteristics & $\begin{array}{l}\text { Coeffi- } \\
\text { cients }\end{array}$ & $\begin{array}{c}\text { Standard } \\
\text { error }\end{array}$ & $t$ stat. & $p$-value & $\begin{array}{c}\text { Lower } \\
95 \%\end{array}$ & $\begin{array}{c}\text { Upper } \\
95 \%\end{array}$ \\
\hline Intercept & 602.278 & 361.588 & 1.666 & 0.194 & -548.455 & 1753.012 \\
\hline Net income & 0.690 & 0.560 & 1.231 & 0.306 & -1.093 & 2.472 \\
\hline No. of houses & -5.649 & 3.776 & -1.496 & 0.231 & -17.665 & 6.366 \\
\hline Unemployment & -0.047 & 0.162 & -0.290 & 0.790 & -0.564 & 0.469 \\
\hline
\end{tabular}


Table 4. cont.

\begin{tabular}{|c|c|c|c|c|c|c|}
\hline $\begin{array}{c}\text { Regression } \\
\text { statistics }\end{array}$ & \multicolumn{6}{|c|}{ One variable } \\
\hline Multiple $R$ & \multicolumn{6}{|c|}{0.941} \\
\hline$R^{2}$ & \multicolumn{6}{|c|}{0.885} \\
\hline Adjusted $R^{2}$ & \multicolumn{6}{|c|}{0.861} \\
\hline Standard error & \multicolumn{6}{|c|}{2.577} \\
\hline Observations & \multicolumn{6}{|c|}{7} \\
\hline Anova & $d f$ & SS & \multicolumn{2}{|c|}{ MS } & $F$ & Significance $F$ \\
\hline Regression & 1 & 254.354 & \multicolumn{2}{|c|}{254.354} & 38.312 & 0.002 \\
\hline Residual & 5 & 33.195 & \multicolumn{2}{|c|}{6.639} & - & - \\
\hline Total & 6 & 287.549 & \multicolumn{2}{|c|}{-} & - & - \\
\hline Characteristics & $\begin{array}{l}\text { Coeffi- } \\
\text { cients }\end{array}$ & $\begin{array}{c}\text { Standard } \\
\text { error }\end{array}$ & $t$ stat. & $p$-value & $\begin{array}{c}\text { Lower } \\
95 \%\end{array}$ & Upper 95\% \\
\hline Intercept & 1126.319 & 167.125 & 6.739 & 0.001 & 696.711 & 1555.927 \\
\hline $\begin{array}{l}\text { No. of houses/ } \\
\text { population }\end{array}$ & -10.252 & 1.656 & -6.190 & 0.002 & -14.510 & -5.994 \\
\hline
\end{tabular}

When the purpose of a multivariable regression analysis is to explain the individual effects of the predictors on an outcome variable, it is important that a potential multicollinearity between the predictors be investigated and the correlated variables (which convey the same information) should be removed. Due to the multicollinearity between the variables, more regressions were conducted using different combinations of independent variables as well as using each independent variable individually. Table 4 also shows the results of the regression analysis using only the number of houses.

The results indicated that the Significance F value was reduced to 0.002 and the $p$-value was also reliable, which means that, out of all three of the independent variables used in this study, the number of houses is the most significant one. The slope of the variable is also theoretically correct. The results show that, if the number of houses increases by one unit, housing prices decrease by 10.252 units. The computed $R^{2}$ was $88.5 \%$. Adjusted for its degrees of freedom (adjusted $R^{2}$ ), it remained very high $(86.1 \%)$.

\section{Conclusions}

For most people around the world, their home is the primary investment they make, so understanding the residential market is far more important than any other kind of real estate market. The demand for houses is directly connected to variables 
such as income and unemployment, which then influence the prices. The house prices are also affected by the quantity of newly constructed houses and their respective building costs.

The purpose of this study was to compare the housing prices in Warsaw and Lisbon during the period of 2009-2015 and determine which of the three selected macroeconomic variables play a significant role in affecting housing prices in both cities.

We investigated the following factors: wages, number of houses/population, and unemployment/population, and our findings confirm that these chosen macro factors indeed influence housing prices. An increase in wages appears to have a positive effect on housing prices, while increases in the number of houses and the unemployed population have a negative influence on the prices. The results of our simple regressions revealed that there were some similarities and some differences regarding how each of the chosen factors influenced the housing prices in both cities.

Our regression models helped us identify which factors were more significant in affecting the housing factors in both cities. After multiple regressions, we finally managed to choose one factor (namely, the no. of houses) that was considered the most influential factor in determining the prices in Lisbon. Meanwhile, the regression model appeared to be invalid in the case of Warsaw, which means that none of the chosen factors apparently influence housing prices in Warsaw.

In conclusion, this study helped us develop a model to determine how and to what extent the chosen macro factors affect housing prices in Lisbon. However, in the case of Warsaw, the model is not reliable, so more research should be done to construct a reliable one.

\section{References}

[1] Bryx M.: Rynek nieruchomości a procesy rewitalizacji miast. [in:] Bryx M. (red.), Rynek nieruchomości. Finansowanie rozwoju miast, CeDeWu, Warszawa 2013, pp. 31-44.

[2] von Thünen J.H.: Der Isolierte Staat in Beziehung auf Landwirthschaft und Nationalökonomie. Wiegandt, Berlin 1875.

[3] Christaller W.: Die zentralen Orte in Süddeutschland. Eine ökonomisch-geographische Untersuchung über die Gesetzmässigkeit der Vorbreitung und Entwicklung der Siedlungen mit städtischen Funktionen. Gustav Fischer Verlag, Jena 1933.

[4] Alonso W.: Location and Land Use: Toward a General Theory of Land Rent. Harvard University Press, Cambridge (MA, USA) 1964.

[5] Muth R.F.: Cities and Housing: The Spatial Pattern of Urban Residential Land Use. University of Chicago Press, Chicago 1969.

[6] Goddard G.J., Marcum B.: Real Estate Investment: A Value Based Approach. Springer, Berlin - Heidelberg - Dordrecht - London - New York 2012. 
[7] Isard W.: Location and space-economy: a general theory relating to industrial location, market areas, land use, trade, and urban structure. Technology Press of Massachusetts Institute of Technology and John Wiley \& Sons, New York 1956.

[8] Meen G.: Modelling Spatial Housing Markets: Theory: Analysis and Policy, Volume 2. Springer Science+Business Media, New York 2001.

[9] Kucharska-Stasiak E.: Nieruchomość w gospodarce rynkowej. Wydawnictwo Naukowe PWN, Warszawa 2006.

[10] Lund B.: Understanding Housing Policy. $2^{\text {nd }}$ ed. Policy Press, Bristol 2014.

[11] Ranci C., Brandsen T., Sabatinelli S. (eds.): Social Vulnerability in European Cities: The Role of Local Welfare in Times of Crisis. Palgrave Macmillan, London 2014.

[12] Dziauddin M.F., Ismail K., Othman Z.: Analysing the Local Geography of the Relationship Between Residential Property Prices and Its Determinants. Bulletin of Geography. Socio-economic Series, vol. 28, issue 28, 2015, pp. 21-35.

[13] Belej M., Kulesza S.: Similarities in Time-Series of Housing Prices on Local Markets in Poland. Real Estate Management and Valuation, vol. 22, no. 3, 2014, pp. 45-53.

[14] Rącka I.: Jakość informacji na rynku nieruchomości w Polsce [The Quality of Information on the Real Estate Market in Poland]. Problemy Jakości, nr 4, 2017, pp. 19-25.

[15] Gostkowska-Drzewicka M.G.: Housing Markets in Selected European Countries and the USA. e-Finanse: Financial Internet Quarterly, vol. 8 (1), 2012, pp. 23-37.

[16] Sitek M.: Situation in the Polish housing market compared to other EU countries. Journal of International Studies, vol. 7, no. 2, 2014, pp. 57-69.

[17] Heritage, [on-line:] https://www.heritage.org/index/ranking [access: 27.04.2018].

[18] Statistics Poland: Housing construction in the period of January-December 2016, [on-line:] https://stat.gov.pl/en/topics/industry-construction-fixed-assets/construction/housing-construction-in-the-period-of-january-december-2016,3,55.html [access: 27.04.2018].

[19] Siemińska E., Rymarzak M.: Development Conditions of Polish Housing Market During Economic Crisis. Real Estate Management and Valuation, vol. 22, issue 4, 2014, pp. 68-80.

[20] Augustyniak H., Łaszek J., Olszewski K., Waszczuk J.: Housing market cycles - a disequilibrium model and its calibration to the Warsaw housing market. [in:] The Narodowy Bank Polski Workshop: Recent Trends in the Real Estate Market And its Analysis, 2013, [on-line:] https://ssl.nbp.pl/badania/konferencje/2013/ realestateworkshop/pdf/housing_market_cycles_\%E2\%80\%93_a_disequilibrium_model_and_its_calibration_to_the_warsaw_housing_market.pdf [access: 27.04.2018]. 
[21] Moreira A.C., Tavares F.O., Pereira E.T.: Valoración Inmobiliaria. Aplicación del Método de Rentas en los Municipios Portugueses. Revista galega de economía, no. 23(1), 2014, pp. 187-202.

[22] Tavares F.O., Pereira E.T., Moreira A.C.: The Portuguese residential real estate market. an evaluation of the last decade. Panoeconomicus, no. 6, 2014, pp. 739-757.

[23] Deloitte: Property index - Overview of European Residential Markets, What Size of Dwelling Can People Buy for EUR 200,000. $5^{\text {th }}$ ed., July 2016, [on-line:] https://www2.deloitte.com/content/dam/Deloitte/cz/Documents/survey/ Property_Index_2016_EN.pdf [access: 27.04.2018].

\section{Rynek mieszkaniowy w stolicach państw - przykład Polski i Portugalii}

Streszczenie: Rynki nieruchomości w stolicach państw znacznie różnią się od tych w innych regionach krajów. Rynki w stolicach - ze względu na wyższy poziom inwestycji, działalności gospodarczej i dochodów, wzrost turystyki i popyt na nieruchomości, a w konsekwencji wyższe ceny - są zazwyczaj bardziej rozwinięte i wartościowe, ale w pewnym stopniu decydują o poziomie rozwoju krajowego rynku nieruchomości. Celem artykułu jest przeprowadzenie analizy porównawczej cen mieszkań w Warszawie i Lizbonie, stolicach Polski i Portugalii, z wykorzystaniem niektórych zmiennych makroekonomicznych oraz pomiar wpływu czynników, w tym płac, podaży domów i bezrobocia, na ceny mieszkań w obu miastach. Analizą objęto lata 2009-2015. W badaniach wykorzystano następujące metody badawcze: przegląd literatury, badania źródeł wtórnych danych, metody statystyczne (korelacja, regresja prosta i wielokrotna). Ustalono, które czynniki i w jakim stopniu wpływają na ceny mieszkań w Warszawie i Lizbonie.

Słowa

kluczowe: mieszkalnictwo, rynek nieruchomości mieszkaniowych, zmiany cen 